\title{
Effective Implementation of Outcome-based Education: The Role of Faculty Awareness
}

\author{
Srinivasa Pai P1* Gururaj Upadhyaya ${ }^{2}$ (iD \\ 1,2Department of Mechanical Engg., NMAM Institute of Technology, Karnataka, India \\ *Corresponding author: srinivasapai@nitte.edu.in
}

\section{Abstrak}

Akreditasi institusi teknis sangat penting untuk menjamin kualitas pendidikan teknik yang ditawarkan. Pendidikan berbasis hasil (OBE) diikuti dalam penyampaian pendidikan teknis di semua Institusi di India dan Dewan Akreditasi Nasional (NBA), yang merupakan badan akreditasi nodal untuk institusi teknis di India mengikuti akreditasi berbasis hasil (OBA) dalam akreditasi dari program teknis. Dalam OBE dan OBA, fakultas merupakan komponen terpenting dan berperan penting dalam memfasilitasi hal yang sama. Sehubungan dengan hal tersebut, penulis merasa perlu untuk memahami tingkat kesadaran fakultas tentang hal yang sama dan oleh karena itu survei dilakukan di antara fakultas lembaga penulis, yang merupakan Lembaga otonom dan berada di bawah skema Tier I. Proses akreditasi NBA. Dari 285 anggota fakultas, sekitar 96 berpartisipasi dalam survei. Makalah ini membahas tentang pentingnya kesadaran dan keterlibatan fakultas dalam proses akreditasi dan implementasi OBE. Hasil survei menunjukkan beberapa temuan menarik, yang dibahas secara rinci. Beberapa saran dan pedoman diberikan di bagian akhir untuk meningkatkan tingkat kesadaran dan keterlibatan mereka masing-masing dalam proses $O B E$ dan $O B A$.

Kata kunci: Pendidikan Berbasis Hasil, Akreditasi, Fakultas, Institusi, Kesadaran

\begin{abstract}
Accreditation of technical institutions is very important to guarantee the quality of technical education that is being offered. Outcome based education (OBE) is followed in the delivery of technical education across all Institutions in India and the National Board of Accreditation (NBA), which is the nodal accreditation body for technical institutions in India follows outcome based accreditation (OBA) in the accreditation of technical programs. In the OBE and OBA, faculty constitutes the most important component and plays an important role in facilitation of the same. In this regard, the authors felt that there is a need to understand the level of awareness of faculty about the same and accordingly a survey was conducted among the faculty of the authors' institution, which is an autonomous Institution and comes under Tier I scheme of NBA accreditation process. From among 285 faculty members, about 96 participated in the survey. This paper discusses the significance of faculty's awareness and involvement in the accreditation process and implementation of OBE. The results of the survey indicate some interesting findings, which is discussed in detail. Some suggestions and guidelines are given at the end to increase the level of awareness and their involvement in the OBE and OBA processes respectively.
\end{abstract}

Keywords: Outcome-Based Education, Accreditation, Faculty, Institution, Awareness

$\begin{array}{ll}\text { History: } & \text { Publisher: Undiksha Press } \\ \text { Received : August 28, 2021 } & \text { Licensed: This work is licensed under } \\ \text { Revised : August 29, } 2021 & \text { a Creative Commons Attribution 3.0 License } \\ \text { Accepted : September 30, } 2021 & \text { CC C) (O) } \\ \text { Published : October } 25,2021 & \end{array}$

\section{INTRODUCTION}

Outcome based education (OBE) has been in existence for quite a long time and it has been applicable for all forms of education. Outcome is the basis of education, which is "demonstration of learning". It is what the student should be able to do at the end of a course. In this approach to education, the curriculum is based on the learning outcomes. It can be considered as "result-oriented" thinking and is the anti-thesis of 'input-based' education, where product is more important than the process (Davis, 2003; Tan et al., 2018). OBE addresses various questions like - what the students need to learn? Why they need to learn it? how can the teacher best help students to learn it? And how do the teachers know that students have learnt it? (Jadhav et al., 2020; Premalatha, 2019) It can be applied to different forms of education, including in managerial accounting course by the authors in Hong Kong, 
which was considered as successful (Kwok, 2000; Lui \& Shum, 2012). OBE requires a future-driven curriculum focus and requires performance assessment (Hoffman, 1996). The outcomes of the teaching-learning process are used to drive instructional and curricular decisions and instructions. OBE has several advantages and include student learning outcomes are publicly stated and provides clear guidance for instruction and assessment. If implemented properly, it increases accountability for both teachers and students. If the student demonstrates that he / she has acquired necessary knowledge, skills and competencies, as described in the outcomes, that means he / she has acquired quality education. The curriculum designed in OBE is based on broad and visionary goals, which enables students to do well after their education.

OBE is a student-centred approach, where the focus is not what the teacher wants to teach or achieve, but what the learner should know, understand, demonstrate and become (Bhat et al., 2020; Mitra \& Gupta, 2020). All the stakeholders have a role to play in this education system, students have to take responsibility for their learning, teachers have to properly plan and manage the student's learning environment and parents have to motivate and help their children to learn. With regard to the implementation issues, most of the teachers feel comfortable with the current system, they lack understanding of the principles of $\mathrm{OBE}$ and there is a need for a structured training program regarding OBE (Zakaria \& Yusoff, 2010). In a review of the literature, the role of faculty for undertaking this shift from old educational system to OBE is a crucial factor, which need to be considered as a policymaking decision (Hejazi, 2011; Sun \& Lee, 2020). There is a need to evolve a reward-based mechanism to support the efforts of the faculty in adopting OBE. There is a need for doing significant changes to most of the institutional policies, procedures and structures for OBE implementation. There is a need for a SWOT analysis to understand the new role of faculty in OBE (Hejazi, 2011). The development of effective and efficient methods to help faculty to adopt OBE in engineering programs in Canadian Universities (Akhmadeeva et al., 2013). The paper emphasizes the need for changes in pedagogy, attitudes of faculty and forms of assessment for achieving continuous improvement in OBE. The issues considered important were class size, expectations of learner characteristics and reality, teaching practice and evaluation and student motivation. The paper identified contradictions among the faculty regarding perceived and their actual role as per OBE. It emphasizes that transition to OBE would provide challenges and opportunities (Akhmadeeva et al., 2013). The implementation of OBE at University of Perpetual Help System, Philippines regarding attaining intended student outcomes, relevance of intended student outcomes, course organization, instructional process and support for instruction and assessment. The faculty and students were convinced about its benefits and suggested several areas of improvement (Custodio et al., 2017).

OBE and OBA are meant to improve the quality of technical education in the technical institutions. ISO 9000 standards are meant for improving the quality of products, processes and services offered by industries. Efforts are being made in private technical educational institutions to adopt ISO 9000 standards, to either supplement the efforts of accreditation or as a means to streamline the processes in educational institutions independently and have a quality management system (QMS) in place. The need for developing a methodology for implementing ISO 9000 and European Quality Award (EQA) through ABET accreditation to avoid waste of time and money in duplication of efforts involved in implementing them independently. This helps in producing engineers, who are globally competitive, who in turn help in producing high quality products, processes and services (Thandapani et al., 2011, 2013). The current status of Indian technical educational institutions, both quantitatively and qualitatively and emphasizes the need for accreditation for quality improvement and quality assurance of educational programmes (Prasad \& Bhar, 2010). They analyse the current status of accreditation of technical programmes in India and 
compare the accreditation framework adopted by some important countries who are either signatories or provisional members of Washington Accord. They identify the strengths from among these procedures, which are followed by NBA and identify weaknesses which need attention and give recommendations to overcome the same, to make the Indian accreditation system more effective and acceptable to various stakeholders of the technical education of the country (Prasad \& Bhar, 2010).

Previous study identified the level of knowledge and practice about OBE implementation at the College of Engineering of Lyceum of the Philippines University Batangas during the first semester of 2013-2014 (Laguador \& Dotong, 2014). It was found that faculty are well versed in terms of knowledge and practice on OBE implementation, but there is a moderate understanding about the suitable assessment method to be used. It was suggested that better understanding by faculty about OBE implementation can help in better contribution and realization of the objectives of OBE through practice. Continuous participation by faculty through training programs was recommended. Follow up studies was recommended to understand the problems faculty face in fulfilling OBE requirements (Laguador \& Dotong, 2014). Other study was conducted to understand, plan and implement $\mathrm{OBE}$ at their institute. A mechanism was designed and developed regarding collection of all necessary data and fact required for OBE. The authors found that use of OBE helps in improving design of curriculum, content delivery to the students and the assessment methods adopted. They found that without proper planning, implementation of OBE becomes very difficult (Hejazi, 2011). This brief literature review looks at various issues affecting OBE implementation and among these faculty is very important. Faculty play a crucial role in OBE implementation, as they teach courses and assess them and help in achieving the course outcomes, which is the fundamental level in OBE. There is a lack of general awareness among the faculty about OBE, its different components like course outcomes, program outcomes, Bloom's taxonomy levels etc., and this is going to affect the implementation process significantly. Faculty particularly in private institutions involve themselves in OBE process without a proper understanding and hence fail to contribute effectively during the accreditation process. The beneficiaries of OBE namely the students are not able to get the full benefits due to this lack of understanding and awareness (Pai et al., 2019).

Accreditation ascertains the quality of education provided to the students (Augusti, 2007; Prasad \& Bhar, 2010). Accreditation is a process of quality assurance and improvement, whereby a programme in an approved institution is critically appraised to verify that the institution or programme continues to meet and / or exceed the norms and standards prescribed by the regulator from time to time (Levy, 2000; McDermott et al., 2004; Natarajan, 2000). The accreditation process followed by NBA is based on the framework of OBE (Blom \& Cheong, 2010; Stella, 2004). NBA has taken up the onerous job of accrediting the engineering programs of different classes of institutions in this country. But the number of institutions that are offering engineering programs is so large, it has become a huge task for the agency to do the job. Among the various issues affecting the accreditation process of engineering programs in engineering colleges, the lack of clarity among the teachers about OBE, its need, importance and implementation is a major issue. Accreditation is no longer a choice, but a compulsion which all engineering colleges have to undergo for achieving acceptability in the general society and make our technical education more acceptable in the global community. This problem is equally true both in private and govt. institutions and there is a need to understand the issues concerning this, as teachers play a major role in accreditation of the engineering programs in an institution. In this regard, this paper tries to understand the perception of faculty about OBE and its related issues. A sample survey was conducted among all the faculty of the author's institution, which is an autonomous institution coming under Tier I category. The results revealed interesting observations and the 
views of the faculty were collected and analysed to understand how to improve the implementation of OBE for achieving accreditation to the satisfaction of all stake holders.

\section{METHODS}

A questionnaire based on the work of Hoffman T.G and Learning Outcomes Questionnaire developed for Alberta, Canada for public post-secondary educational institutions in 2016 was suitably modified to get the feedback from faculty members regarding their awareness about the accreditation process (Hoffman, 1996). The questionnaire had two sections, the first collected personal details like name, designation, department and sex. The second section had 21 questions seeking feedback from faculty regarding various aspects of the accreditation process, like does the institution has a mission statement, vision statement, is there a difference between course objectives and course outcomes, does the board of studies (BOS) play a major role in monitoring the effective implementation of course outcomes and program outcomes through regular improvement in teaching-learning process and assessment etc. The last question was an open ended question, which was asking suggestions for improving implementation of OBE in the department. Questionnaire is considered as a key quantitative method, as large number of participants can participate and access the questionnaire easily and with minimum time. Further researchers feel that it is a systematic method which facilitates statistical evaluation of the data (Alghamdi, 2016). Table 1 gives the purpose of the questions included in the questionnaire.

Table 1. Purpose of Questions in the Questionnaire.

\begin{tabular}{ll}
\hline Survey Questions & \multicolumn{1}{c}{ Purpose } \\
\hline Q 1, 2, 3, 4 5 & $\begin{array}{l}\text { To understand about the presence of vision, mission statement } \\
\text { and their significance. } \\
\text { To understand about course outcomes (CO), program outcomes } \\
\text { (PO), their attainment, assessment, need to modify the same and } \\
\text { about course objectives. } \\
\text { To understand about the role of Board of Studies in the overall } \\
\text { OBE scheme. } \\
\text { To understand the awareness of OBE among students and effects } \\
\text { of its effective implementation } \\
\text { Suggestions for improving implementation of OBE in the } \\
\text { department }\end{array}$ \\
\hline
\end{tabular}

The faculty members were from all engineering departments (civil, mechanical, electrical, electronics, computer science, information science and biotechnology) and basic science departments (mathematics, physics, chemistry and humanities). About 96 faculty members out of a total of 285 participated in the survey (response rate is 33.7\%), which is a very good percentage. The reason for going for a larger sample is to gain a wider view and also generalize the findings.

\section{RESULTS AND DISCUSSION}

\section{Results}

\section{Pilot study}

A pilot study was conducted about this questionnaire among the faculty of Mechanical Engg. department to know whether the faculty would understand the meaning of the questions framed for ascertaining their feedback. The results of this study was 
communicated in the form of an educational conference paper and it was encouraging (Pai et al., 2019). The faculty had no issues understanding the questions.

\section{Study findings}

A total of 96 responses were received. A total of 5 Head of Departments, One Vice Principal, 9 Professors, 15 Associate Professors and remaining 66 Assistant Professors answered the survey. Fig. 2 shows the distribution across different departments. Out of the total 96 responses, 28 were female faculty $(29.17 \%)$ and the remaining 68 were male faculty $(70.83 \%)$. The findings reveal that a good number of senior faculty $(15.6 \%)$ answered the questionnaire which establishes the commitment of senior faculty in successful implementation of accreditation.

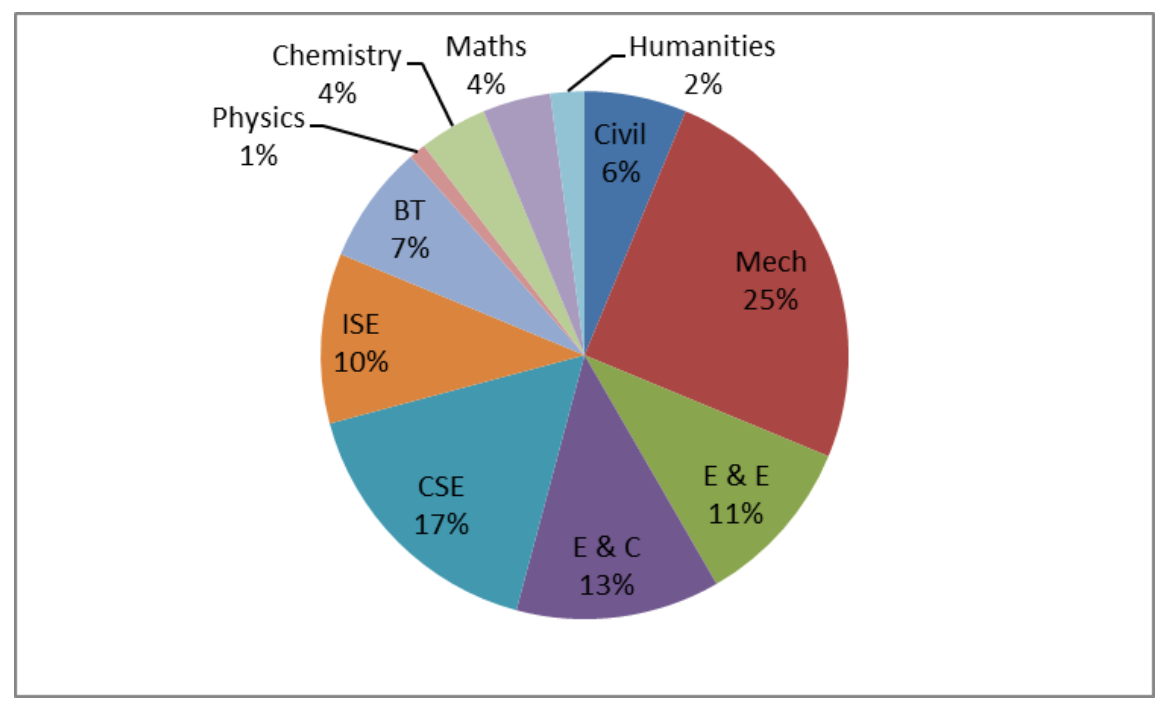

Fig. 1. Faculty distribution across departments

\section{Sampling size and adequacy}

In general, the sample size should be adequate to enable generalization or sample characteristics should project the population characteristics. It was expected that a minimum sample size of 30 should be obtained, as the minimum acceptable sample size for correlational research or causal-comparative research is 30 . Table 2 provides the results regarding checking the sampling size and adequacy.

Table 2. KMO and Bartlett's Test.

\begin{tabular}{ll}
\hline \multicolumn{1}{c}{ Statistic } & \multicolumn{1}{c}{ Value } \\
\hline Kaiser-Meyer-Olkin Measure of Sampling Adequacy. & 0.966 \\
Bartlett's Test of Sphericity & 4488.591 \\
Approx. Chi-Square & 210 \\
df & 0.000 \\
Sig. & The degree to which a data set provides empirical evidence for the appropriateness of
\end{tabular}
a factor analysis solution can be assessed by determining a measure of sampling adequacy. The Kaiser - Meyer - Olkin (KMO) measure of sampling adequacy, which is an option offered by SPSS software (SPSS v 12.0), was used to measure the adequacy of the sample. High values (between 0.5 and 1.0) of Kaiser-Meyer-Olkin (KMO) measure of sampling adequacy indicate that the sample considered is appropriate. 


\section{Overview of the responses to the questionnaire items}

Based on the purpose of questions in the questionnaire, Table 3, 4,5 and 6 presents the response to the questions in that group for different scales with regard to the total number of respondents. These results give a general overview about the responses received. The responses in Table 3 show some interesting results. For question 1 and 2, the strongly agree and strongly disagree options selected are almost very close. This means about $50 \%$ of the faculty agree that the institution has a vision and mission statement and other $50 \%$ think there is no such statements. About $47 \%$ of the faculty agree that there is a relationship between vision and mission statement. Only $33.33 \%$ faculty agree that the mission statement reflects the commitment of the institution to help students to become successful and about 50 $\%$ of the faculty agree that the institution is committed to the mission statement.

Table 3. Responses Corresponding to Vision, Mission Statement and Their Significance

\begin{tabular}{|c|c|c|c|c|c|}
\hline Questionnaire item & $\begin{array}{l}\text { Strongly } \\
\text { agree } \\
(\%)\end{array}$ & $\begin{array}{c}\text { Agree } \\
(\%)\end{array}$ & $\begin{array}{l}\text { Does } \\
\text { not } \\
\text { apply } \\
(\%)\end{array}$ & $\begin{array}{l}\text { Disagree } \\
(\%)\end{array}$ & $\begin{array}{l}\text { Strongly } \\
\text { disagree } \\
(\%)\end{array}$ \\
\hline Institution has a vision statement & 43.75 & 4.17 & 0 & 6.25 & 45.83 \\
\hline Institution has a mission statement & 42.7 & 5.2 & 0 & 6.25 & 45.83 \\
\hline $\begin{array}{l}\text { There is a relationship between vision } \\
\text { and mission statement }\end{array}$ & 37.5 & 10.42 & 0 & 10.42 & 41.67 \\
\hline $\begin{array}{l}\text { Mission statement reflects a } \\
\text { commitment to enable all students to } \\
\text { be successful }\end{array}$ & 33.33 & 13.54 & 1.04 & 22.92 & 29.17 \\
\hline $\begin{array}{l}\text { Institution is committed to the } \\
\text { mission statement }\end{array}$ & 32.3 & 17.7 & 0 & 15.6 & 34.4 \\
\hline
\end{tabular}

Table 4 gives the details of the responses regarding awareness of faculty regarding COs, POs, their attainment, assessment, need to modify the same and about course objectives. There is a near $50 \%$ agreement and more than $50 \%$ disagreement with various aspects covered in the questionnaire, which means more than $50 \%$ of the faculty are not aware about these aspects, which are crucial for OBE implementation. For eg., only $47 \%$ of the faculty have awareness about the method used in their department for assessing CO based on CIE and SEE and the remaining are not aware of the same. Only about $44 \%$ agree that course objectives are different from COs. Table 5 gives information about the role of BOS in supporting the effective implementation of OBE. BOS is an important statutory body of any autonomous institution / University, which is authorized to make changes to the curriculum on a regular basis based on the requirements like changes in technology, advancements, job prospects, imparting of knowledge, skills and attitude. About $49 \%$ fully agree about its role and the remaining do not understand or agree with its role.

Table 4. Responses Corresponding to Course Outcomes, Program Outcomes, Their Attainment, Assessment, Need to Modify the Same and About Course Objectives

\begin{tabular}{lccccc}
\hline \multicolumn{1}{c}{ Questionnaire item } & $\begin{array}{c}\text { Strongly } \\
\text { agree } \\
(\mathbf{\%})\end{array}$ & $\begin{array}{c}\text { Agree } \\
(\mathbf{\%})\end{array}$ & $\begin{array}{c}\text { Does not } \\
\text { apply } \\
(\boldsymbol{\%})\end{array}$ & $\begin{array}{c}\text { Disagree } \\
(\mathbf{\%})\end{array}$ & $\begin{array}{c}\text { Strongly } \\
\text { disagree } \\
(\mathbf{\%})\end{array}$ \\
\hline $\begin{array}{l}\text { Program Outcomes (PO) are } \\
\text { common for all disciplines. }\end{array}$ & 31.25 & 19.79 & 1.04 & 33.33 & 14.58 \\
POs have been taken from NBA & 35.47 & 13.54 & 2.08 & 8.33 & 40.62 \\
\hline
\end{tabular}




\begin{tabular}{|c|c|c|c|c|c|}
\hline Questionnaire item & $\begin{array}{l}\text { Strongly } \\
\text { agree } \\
(\%)\end{array}$ & $\begin{array}{c}\text { Agree } \\
(\%)\end{array}$ & $\begin{array}{l}\text { Does not } \\
\text { apply } \\
(\%)\end{array}$ & $\begin{array}{l}\text { Disagree } \\
(\%)\end{array}$ & $\begin{array}{c}\text { Strongly } \\
\text { disagree } \\
(\%)\end{array}$ \\
\hline \multicolumn{6}{|l|}{ document. } \\
\hline $\begin{array}{l}\text { The Course Outcomes }(\mathrm{CO}) \\
\text { developed for the course support } \\
\text { the attainment of POs. }\end{array}$ & 29.17 & 18.75 & 1.04 & 19.79 & 31.25 \\
\hline $\begin{array}{l}\text { Course objectives are different } \\
\text { from COs. }\end{array}$ & 19.79 & 23.96 & 9.37 & 18.75 & 28.12 \\
\hline $\begin{array}{l}\text { The curriculum is regularly revised } \\
\text { to match the COs. }\end{array}$ & 26.04 & 21.87 & 3.12 & 21.87 & 27.08 \\
\hline $\begin{array}{l}\text { There are different teaching } \\
\text { methods to teach the course } \\
\text { content to achieve the COs. }\end{array}$ & 23.96 & 23.96 & 2.08 & 27.08 & 22.92 \\
\hline $\begin{array}{l}\text { The questions set in the } \\
\text { assessment are framed such that } \\
\text { students can demonstrate the } \\
\text { attainment of COs. }\end{array}$ & 26.04 & 18.75 & 3.12 & 17.71 & 34.37 \\
\hline $\begin{array}{l}\text { Awareness about method adopted } \\
\text { to assess the COs based on CIE } \\
\text { and SEE. }\end{array}$ & 32.29 & 14.58 & 2.08 & 15.62 & 35.42 \\
\hline $\begin{array}{l}\text { Procedure to map the attainment of } \\
\text { COs to the POs. }\end{array}$ & 28.12 & 18.75 & 2.08 & 18.75 & 32.29 \\
\hline $\begin{array}{l}\text { Need to modify the COs based on } \\
\text { the attainment. }\end{array}$ & 16.67 & 19.79 & 19.79 & 28.12 & 15.62 \\
\hline
\end{tabular}

Table 5. Responses corresponding to role of BOS in the overall OBE scheme

\begin{tabular}{llllll}
\hline Questionnaire item & $\begin{array}{l}\text { Strongly } \\
\text { agree } \\
(\boldsymbol{\%})\end{array}$ & $\begin{array}{l}\text { Agree } \\
(\boldsymbol{\%})\end{array}$ & $\begin{array}{l}\text { Does } \\
\text { apply }(\boldsymbol{\%})\end{array}$ & $\begin{array}{l}\text { Dot } \\
(\boldsymbol{\%})\end{array}$ & $\begin{array}{l}\text { Strongly } \\
\text { disagree } \\
(\boldsymbol{\%})\end{array}$ \\
\hline $\begin{array}{l}\text { Board of Studies plays a major } \\
\text { role in effective implementation } \\
\text { of COs and POs. }\end{array}$ & 30.20 & 18.75 & 3.12 & 29.17 & 18.75 \\
\hline
\end{tabular}

Table 6 is concerned with questions about are students aware of OBE, are efforts being made to create awareness about them, does OBE implementation makes students and teachers more responsible and is there an improvement in performance of students and teachers. Only about $50 \%$ agree with these questions and the remaining $40 \%$ do not agree and interestingly on an average $12 \%$ do not think it is relevant. This is again a cause for concern, as the students are the end beneficiaries of OBE implementation. If the faculty are not able to understand about the awareness of OBE among students and the effects of its effective implementation, then the real results of OBE cannot percolate down and reach the students and make their teaching-learning experiences meaningful. 
Table 6. Responses Corresponding to Understanding the Awareness of Obe Among Students and Effects of Its Effective Implementation

\begin{tabular}{|c|c|c|c|c|c|}
\hline Questionnaire item & $\begin{array}{l}\text { Strongly } \\
\text { agree } \\
(\%)\end{array}$ & $\begin{array}{l}\text { Agree } \\
(\%)\end{array}$ & $\begin{array}{l}\text { Does not } \\
\text { apply } \\
(\%)\end{array}$ & $\begin{array}{l}\text { Disagree } \\
(\%)\end{array}$ & $\begin{array}{l}\text { Strongly } \\
\text { disagree } \\
(\%)\end{array}$ \\
\hline 17. Students are aware about OBE. & 18.75 & 25 & 10.42 & 26.04 & 19.79 \\
\hline $\begin{array}{l}\text { 18.Efforts made to } \begin{array}{r}\text { create } \\
\text { awareness about OBE among } \\
\text { students }\end{array} \\
\end{array}$ & 25 & 22.92 & 4.17 & 20.83 & 27.08 \\
\hline $\begin{array}{l}19 . \mathrm{OBE} \text { implementation makes } \\
\text { teachers and students more } \\
\text { responsible. }\end{array}$ & 26.04 & 21.87 & 6.25 & 26.04 & 19.79 \\
\hline $\begin{array}{llr}\begin{array}{l}\text { 20.Improvement } \\
\text { performance }\end{array} & \text { in } & \text { student } \\
\text { implementation. } & & \text { OBE } \\
\text { implem } & & \end{array}$ & 19.79 & 20.83 & 17.7 & 30.2 & 11.46 \\
\hline $\begin{array}{l}\text { 21.Implementation of OBE has } \\
\text { helped in becoming a 'successful } \\
\text { teacher'. }\end{array}$ & 23.96 & 18.75 & 11.46 & 34.37 & 11.46 \\
\hline
\end{tabular}

\section{One Sample test}

One sample test was conducted to understand the relevance of 21 questions in the questionnaire in terms of accepting or rejecting the null hypothesis. One sample $t$ test indicates that there is no sufficient evidence to reject the null hypotheses at a 2 tailed significance of $\alpha=0.05$ (or 5\%) with respect to all the questions (Q1 to Q21). Conversely this indicates that the respondents do not agree 'significantly' with the 21 statements of the questionnaire. The inability to reject any of the null hypothesis is surprising especially in the case of some straightforward questions. This indicates the lack of awareness among the faculty regarding the aspects of OBE as covered in the questionnaire. Similar analysis carried out designation wise, indicated a similar kind of results, wherein there is no basis to reject the null hypothesis corresponding to all the 21 questions. Also analysis can be carried out department wise.

\section{Discussion}

Faculty of Department of Mechanical Engineering felt that: (1) The curriculum of the course they teach is regularly revised to match the course outcomes, so that students are able to achieve those outcomes; (2) The Board of Studies plays a major role in monitoring the effective implementation of course outcomes and program outcomes through regular improvement in teaching-learning process and assessment; (3) There has been an improvement in student performance after OBE implementation. Similar analysis of results of the perceptions of faculty for other departments was carried out. In Civil engineering department, the faculty felt that there is a need to modify the course outcomes based on the attainment. But in case of all other departments, there were no rejection of null hypotheses, which means the faculty do not fully agree with the statements of the questionnaire as reported in the general case.

This study has been conducted in the author's institution and may not reflect the general trend outside. The findings are a cause for concern and there is a need to address these so that OBE can be implemented effectively in the institution to reap the benefits of the same and also help in the accreditation process. The evaluation of responses under five groups exhibit a common trend, strongly agree and strong disagree percentage is almost equal, which means only about $50 \%$ of the faculty agree with the statements made in the 
question. Only with regard to question 16 concerning the role of BOS in the overall OBE scheme, $30.2 \%$ strongly agree that BOS plays a major role, while $18.75 \%$ strongly disagree. The one sample $t$ test reveals that the faculty do not significantly agree with all the 21 questions. The inability to reject the null hypothesis, reflects the lack of complete awareness about OBE. As evident from the results based on mean values about $50 \%$ agree and the remaining either disagree or strongly disagree. The faculty who agree also may not have a complete understanding about OBE, which can be a hindrance in its proper adoption. The sample of faculty participating in this study reflects the entire cross section of the faculty group and hence the results are representative. There is a need to conduct this survey after creating awareness workshops among the faculty in different departments and there may be a perceptible improvement. An effort in this direction has already started, wherein awareness workshops have been organized in all the departments and faculty have started working in the direction of rewriting course outcomes, mapping COs to POs etc.

Accreditation requires process ownership on the part of each faculty so that course outcomes can be achieved, which in turn can help in achieving POs, PEOs, Mission and Vision of the institution. In the questionnaire the 22nd question was regarding suggestions for implementing $\mathrm{OBE}$ in the department and each faculty was asked to give five important suggestions in decreasing order. Some of the important suggestions given are: (1) Training of faculty to understand OBE implementation on a regular basis; (2) Create awareness among the students about OBE implementation, inform them about course outcomes and course objectives; (3) Adoption of innovative teaching-learning methodology and provide sufficient time in the semester to explore and implement the same; (4) Need for regular revision of vision, mission statements and PEOs; (5) Need to improve the assessment methods so that students understand the courses rather than practice rote learning; (6) Need to revise the threshold in the calculation of attainment of course outcomes; (7) Frame questions and train students so that they can be assessed at higher levels of Bloom's Taxonomy levels namely level 3 and level 4 rather than at level 1 and 2 in continuous internal evaluation and semester end examinations; (8) Need for adopting industry based curriculum to provide exposure to students about the latest trends in technology. Faculty participating in the survey have given many interesting suggestions, which have not been compiled here due to lack of space. The suggestions included creating a conducive environment in the department, no pressure to pursue $\mathrm{PhD}$, focusing on teaching-learning process, less emphasis on examinations, quality of student's intake etc.

There is a need to create a culture in the department and institution regarding OBE, so that its adoption and implementation becomes effortless. The institutions need to take some policy decisions regarding improving the involvement of faculty and students. There is a need for establishing an organizational structure for overseeing implementation of OBE across the institution and conduction of regular awareness workshops at the department level internally to motivate faculty to adopt innovative teaching-learning practices to more effectively implement OBE. Students need to be involved in this process as the final beneficiaries. The management of the institution can motivate faculty by creating a conducive environment for the same in terms of providing necessary infrastructure, facilities, salary, incentives, promotions etc. (Pai et al., 2019).

\section{CONCLUSION}

This paper aims to understand the current state of awareness about outcome-based education and accreditation among the faculty of the author's institution. A questionnaire survey was conducted among faculty across departments and disciplines. 96 faculty participated in the survey and gave their feedback. The findings reveal that there is a general 
awareness among the faculty about OBE, but the understanding is not complete, which is revealed from the results of one sample $t$ test. The suggestions given by the faculty reveals that they have some basic understanding and are serious about implementing the same in their department and institution. They feel the need to conduct regular workshops on OBE and train them regarding the various aspects of the same. There is a need for some policy decisions to be taken to increase and improve the involvement of faculty in the OBE implementation. Accreditation of institutions has become mandatory and in the Indian context, institutions need to be accredited by NBA. Faculty are the most important link in the OBE and they act as connections between students, management and society and any efforts made without involving them will not yield the desired results. Regular and systematic involvement of faculty can improve the implementation and help in getting accreditation for longer duration and promote a continuous cycle of improvement.

\section{ACKNOWLEDGEMENT}

The authors would like to thank all the faculty of NMAM Institute of Technology, who participated in this survey and provided their valuable feedback and spent their valuable time.

\section{REFERENCES}

Akhmadeeva, L., Hindy, M., \& Sparrey, C. J. (2013). Overcoming obstacles to implementing an outcome-based education model: Traditional versus transformational OBE. Proceedings of the Canadian Engineering Education Association (CEEA). https://ojs.library.queensu.ca/index.php/PCEEA/article/view/4913.

Alghamdi, F. A. M. (2016). Understanding the change processes resulting from accreditation of colleges in Saudi Arabia. University of Wollongong. https://www.voced.edu.au/content/ngv:79117.

Augusti, G. (2007). Accreditation of engineering programmes: European perspectives and challenges in a global context. European Journal of Engineering Education, 32(3), 273-283. https://doi.org/10.1080/03043790701276742.

Bhat, S., D’Souza, R., Bhat, S., Raju, R., \& Kumara, B. P. (2020). Effective Deployment of Outcome Based Education: Strategies based on Motivational Models. Journal of Engineering Education Transformations, 33, 164-169. https://doi.org/10.16920/jeet/2020/v33i0/150136.

Blom, A., \& Cheong, J. (2010). Governance of technical education in India: key issues, principles, and case studies. The World Bank.

Custodio, P. C., Espita, G. N., \& Siy, L. C. (2017). The Implementation of Outcome-Based Education: The Case of the University of Perpetual Help System DALTA Las Piñas Campus. International

Conference. http://www.vnseameo.org/InternationalConference2017/materials/12_PerlitaCustodio _GinaEspita_LoureliSiy_Fullpaper.pdf.

Davis, M. H. (2003). Outcome-based education. Journal of Veterinary Medical Education, 30(3), 258-263. https://doi.org/10.3138/jvme.30.3.258.

Hejazi, B. M. (2011). Outcomes-Based Education (OBE): A transformational perspective on quality and mobility in higher education. In Outcomes-Based Education: A Transformational Perspective (pp. 1-30). https://doi.org/10.1.1.731.2777.

Hoffman, T. G. (1996). An examination of outcome-based education practices, standards, and factors that enhance implementation of $O B E$. Iowa State University. https://lib.dr.iastate.edu/rtd/11113/. 
Jadhav, M. R., Kakade, A. B., Jagtap, S. R., \& Patil, M. S. (2020). Impact assessment of outcome based approach in engineering education in India. Procedia Computer Science, 172, 791-796. https://doi.org/10.1016/j.procs.2020.05.113.

Kwok, P. K. (2000). Accreditation of engineering degree courses in Hong Kong. International Journal of Engineering Education, 16(2), 154-157. https://dialnet.unirioja.es/servlet/articulo?codigo=6930534.

Laguador, J. M., \& Dotong, C. I. (2014). Knowledge versus practice on the outcomes-based education implementation of the engineering faculty members in LPU. International Journal of Academic Research in Progressive Education and Development, 3(1), 6374. https://ideas.repec.org/a/hur/ijarpe/v3y2014i1p63-74.html.

Levy, J. (2000). Engineering education in the United Kingdom: standards, quality assurance and accreditation. International Journal of Engineering Education, 16(2), 136-145. https://dialnet.unirioja.es/servlet/articulo?codigo=6930532.

Lui, G., \& Shum, C. (2012). Outcome-Based Education and Student Learning in Managerial Accounting in Hong Kong. Journal of Case Studies in Accreditation and Assessment, 2. https://eric.ed.gov/?id=EJ1057748.

McDermott, K. J., Nafalski, A., \& Göl, Ö. (2004). The quality assurance of engineering programmes at the University of South Australia. Global Journal. of Engineering Education, $8(2)$, 159-166. http://www.wiete.com.au/journals/GJEE/Publish/vol8no2/McDermott.pdf.

Mitra, S., \& Gupta, S. (2020). Mobile learning under personal cloud with a virtualization framework for outcome based education. Education and Information Technologies, 25(3), 2129-2156. https://doi.org/10.1007/s10639-019-10043-z.

Natarajan, R. (2000). The role of accreditation in promoting quality assurance of technical education. International Journal of Engineering Education, 16(2), 85-96. https://doi.org/10.1.1.470.6795.

Pai, S. P., Bhat, K. S., Chiplunkar, N. N., \& Rao, S. B. R. (2019). Awareness of Faculty for implementation of Outcome based education: Need for improvement and way ahead. Proceedings of the 48th ISTE National Annual Faculty Convention -2019 on "Technical Education for Smart Society," 19-25.

Prasad, G., \& Bhar, C. (2010). Accreditation system for technical education programmes in India: A critical review. European Journal of Engineering Education, 35(2), 187213. https://doi.org/10.1080/03043790903497294.

Premalatha, K. (2019). Course and program outcomes assessment methods in outcome-based education: A review. Journal of Education, 199(3), 111-127. https://doi.org/10.1177\%2F0022057419854351.

Stella, A. (2004). External quality assurance in Indian higher education: developments of a decade. Quality in Higher Education, 10(2), 115-127. https://doi.org/10.1080/1353832042000230608.

Sun, P. H., \& Lee, S. Y. (2020). The importance and challenges of outcome-based educationa case study in a private higher education institution. Malaysian Journal of Learning and Instruction, 17(2), 253-278. https://doi.org/10.32890/mjli2020.17.2.9.

Tan, K., Chong, M. C., Subramaniam, P., \& Wong, L. P. (2018). The effectiveness of outcome based education on the competencies of nursing students: A systematic review. Nurse Education Today, 64, 180-189. https://doi.org/10.1016/j.nedt.2017.12.030.

Thandapani, D., Gopalakrishnan, K., Devadasan, S. R., \& Murugesh, R. (2013). Implementation of European Quality Award in engineering educational institutions via accreditation board for engineering and technology. International Journal of Business Excellence, 6(1), 59-76. https://doi.org/10.1504/IJBEX.2013.050576. 
Thandapani, D., Gopalakrishnan, K., Devadasan, S. R., Sreenivasa, C. G., \& Murugesh, R. (2011). ISO 9001: 2000 based quality management system via ABET-based accreditation. International Journal of Productivity and Quality Management, 7(2). https://doi.org/10.1504/IJPQM.2011.038681.

Zakaria, S., \& Yusoff, W. W. (2010). Outcome-based education in a private HIL: perceptions of students. Advances in Management, 3(3). 